\title{
Dynamics of Mechatronics Engineering in Pakistan
}

\author{
Aqeela Mir ${ }^{1}$, Akhtar Nawaz Malik², Javaid Iqbal ${ }^{3}$ \\ ${ }^{1,2,3}$ Department of Mechatronics Engineering, CE\&ME, \\ National University of Science and Technology, \\ Rawalpindi, Pakistan \\ 1aqeela_mir123@hotmail.com, 22anmalik@ceme.nust.edu.pk, 33.iqbal@ceme.nust.edu.pk
}

\begin{abstract}
Mechatronics, being a new engineering discipline in Pakistan, has to face many risks for its successful establishment and growth. Every discipline owes its evolution and progress to the stakeholders, government, universities and experts. This paper discusses the general view of Mechatronics engineering education in Pakistan, the evolution of Mechatronics engineering in Pakistan and the status of Mechatronics in the industries of Pakistan. The paper presents a survey based approach and the use of Cronbach Alpha for assessing reliability of the data.
\end{abstract}

Index Terms - Mechatronics, Evolution, Career, Mechatronics Industry Survey, Cronbach Alpha.

\section{INTRODUCTION}

\section{A. History - Mechatronics}

The word 'engineering' originated when man started inventing devices like wheel and pulley, using his skills. The word engineer originated from the word 'engine', which comes from the Latin word ingenium. Ingenium means "innate quality specifically of mental power". So the word engineer evolved as a person who makes effective and practical inventions. Today the definition of an engineer is a person who has got scientific and technical knowledge and is making use of this knowledge to design, analyze and build functional works. Engineering is a wide discipline with many sub-disciplines dedicated to various fields of study with respect to specific technologies. The history of engineering can be roughly divided into three overlapping revolutionary phases. These are:

\section{1) Pre-Scientific Age}

Before the revolution of science, an engineer was defined as "a constructor of military engines" [1]. Initially, engineering was categorized as: Civil Engineering and Military Engineering. Military Engineering was related to construction of walls to strengthen an army, city, nation etc against attack and involved the manufacturing of military engines. Civil Engineering was related to non-military construction, like construction of bridges and houses. These meanings of engineering are no longer in use now because engineering has expanded to involve variety of disciplines.

\section{2) Industrial Age}

After scientific revolution, modern engineering's first phase emerged. This phase evolved when machines started to replace men in production sector. The traditional artists got converted into professionals. The French led civil engineering by emphasizing on mathematics and worked for the development of engineering education in universities. The British initiated mechanical engineering and autonomous professional societies [2]. With the passage of time, practical thought process transformed into scientific realization in addition to the power of understanding, as engineers worked for the development of mathematical analysis and controlled experiments. Technical training got shifted from learning a trade to university education. Information got spread more rapidly in organized meetings and journal publications as professional societies evolved. After the advent of electricity and mass production, the industrial revolution got driven by many branches of engineering. Chemical and electrical engineering emerged and worked together with chemistry and physics and played essential roles in the evolution of chemical, electrical, and telecommunication industries [3]. Marine engineers tamed the great danger of ocean exploration. Aeronautical engineers transformed the dream of flight into a travel freedom with ease [4]. Control engineers catalyzed the pace of automation. Industrial engineers worked for designing and managing mass production and distribution systems. University engineering curricula got well established and graduate schools emerged. Workshops transformed into the laboratories, industrial research started and individual inventions were organized into systematic innovations.

\section{3) Information Revolution}

After the expansion of graduate education, the evolution of engineering research started. Engineering got catalyzed by evolution of new technologies. Microelectronics, telecommunications and computer engineering joined force to initiate the information revolution. For the development of these new technologies, engineers reshaped themselves by reforming educational programs and expanding research. In depth, engineering research gave rise to new technologies and gave power to the systematic knowledge, the engineering sciences and systems theories in information, computer, control, and communications. The coordination and merger of traditional 
disciplines in the development of new technology became the trend of the future.

In the end of last century the field of engineering was gradually divided into the following categories:

- Civil Engineering

- Aerospace Engineering

- Electrical Engineering

- Chemical Engineering

- Mechanical Engineering

- Computer and Software Engineering etc.

Since, the human race has been swiftly progressing and developing in terms of technology, new fields of engineering have been developed. Although all these fields may be defined in different manners, still there is generally a great overlap. These fields are:

- Molecular Engineering

- Nanotechnology

- MEMS

- Biomedical Engineering

- Bio-Molecular Engineering

- Optical Engineering

- Structural Engineering

- Vehicle Engineering

- Mechatronics etc.

The merger of maximum number of engineering fields occurs in mechatronics. A mechatronics engineer is a person who integrates a number of technologies to produce a working system. The traditional disciplines have gone so far from each other that they can no longer work together. Mechatronics engineering is based on elements of mechanical engineering, electrical and electronic engineering and computer science, but is a distinct discipline in its own right.

\section{EVOLUTION OF MECHATRONICS}

Mechatronics evolved due to cross breeding and merger of various technologies and disciplines, not only merger, it has novelty in it. Basically mechatronics is an industrial driven program because the term mechatronics was first coined by Tetsura Mori of Yaskawa Electric Corp back in 1969. Because of needs of the society and the products that were needed by society, Mechatronics evolved. A pure mechanical, electronic or computer engineer was unable to deal with the problem of design of a product which was mechatronics in nature, electrical or electronics driven and computer controlled.

Some 'traditional' engineers still argue on the fact that a mechatronics engineer does not have his own identity that makes him distinct. But in reality our own research reveals and predicts that almost all the technical knowledge and approximately all working roles in engineering have to be learned and all the technical skills have to be developed in one after completion of an engineering qualification degree at university. Mechatronics engineers start with many different but extremely useful foundation backgrounds and have been well received and welcomed in almost every industry across the world. In fact, it is important to remember that the most mechatronics engineering courses evolved because of the industry pressure for producing more adaptable and multidisciplinary engineers [5].

\section{MECHATRONICS IN PAKISTAN}

A totally new and nascent field of engineering for Pakistan, the "Mechatronics" was pioneered in Pakistan by the NUST College of E\&ME in 1998 [6]. At that time, the society was totally unaware of mechatronics and no one knew about this field. People only had a general idea that it was a blend of Mechanical and Electronics. In 2002, UET Lahore, getting lead from NUST, started its Undergraduate program and later on in 2003 Air University came forward and became the third institute to start an undergraduate Mechatronics Engineering Program in Pakistan. But today some more Universities in Pakistan including UET Taxila (Chakwal Campus), Wah Engineering College and UET Peshawar are offering BE Mechatronics programs. Universities offering mechatronics engineering in Pakistan are listed in Table I.

TABLE I

LIST OF UNIVERSITIES OFFERING MECHATRONICS IN PAKISTAN

\begin{tabular}{|l|l|}
\hline $\begin{array}{l}\text { Program Name and the year of } \\
\text { first intake of students }\end{array}$ & \multicolumn{1}{|c|}{ Institution Name } \\
\hline $\begin{array}{l}\text { B.E. Mechatronics } \\
\text { From Intake of Batch 1998) }\end{array}$ & $\begin{array}{l}\text { College of Electrical and } \\
\text { Mechanical Engineering, } \\
\text { NUST, Rawalpindi }\end{array}$ \\
\hline $\begin{array}{l}\text { B.Sc. Mechatronics \& Control } \\
\text { Engineering } \\
\text { (from intake of Batch 2001) }\end{array}$ & $\begin{array}{l}\text { University of Engineering and } \\
\text { Technology, Lahore (Main } \\
\text { Campus) }\end{array}$ \\
\hline $\begin{array}{l}\text { Bachelor of Mechatronics } \\
\text { Engineering } \\
\text { (From Intake of Batch Fall- } \\
\text { 2003) }\end{array}$ & Air University, Islamabad \\
\hline $\begin{array}{l}\text { B.Sc. Mechatronics \& Control } \\
\text { Engineering } \\
\text { (From Intake of Batch 2004) }\end{array}$ & $\begin{array}{l}\text { University of Engineering and } \\
\text { Technology, Lahore } \\
\text { (Faisalabad Campus) }\end{array}$ \\
\hline $\begin{array}{l}\text { B.Sc. Mechatronics } \\
\text { Engineering } \\
\text { (From Intake of Batch 2005) }\end{array}$ & $\begin{array}{l}\text { Wah Engineering College, Wah } \\
\text { Cantt (affiliated with } \\
\text { University of Engineering and } \\
\text { Technology, Taxila). }\end{array}$ \\
\hline $\begin{array}{l}\text { B.Sc. Mechatronics Engineering } \\
\text { (From Intake of Batch Fall-2005) }\end{array}$ & $\begin{array}{l}\text { University of Engineering and } \\
\text { Technology, Taxila (Chakwal } \\
\text { Campus) }\end{array}$ \\
\hline $\begin{array}{l}\text { B.Sc. Mechatronics Engineering } \\
\text { (Intake Batch 2007 ) }\end{array}$ & $\begin{array}{l}\text { NWFP University } \\
\text { of Engineering \& } \\
\text { Technology,Pesha } \\
\text { war (Main } \\
\text { Campus) }\end{array}$ \\
\hline
\end{tabular}

A brief history of Mechatronics in above mentioned engineering institutions is as follows: 


\section{A. History of Mechatronics in Universities of Pakistan}

In today's world, almost all production processes and production lines working in the industry are electromechanical in nature. It is unavoidable for the people working on those process and production lines to have all the knowledge of all the concerned systems. Currently, the employees get training while doing on the job training but it is not so helpful for them because they lack the required theoretical knowledge. The College after realizing this difference between national industrial requirements being aware of world's need and the contents of curriculum gave rise to Mechatronics Engineering from January 1999 at the undergraduate level. MS leading to $\mathrm{PhD}$ program in Mechatronics engineering started in the College in 2005. The Masters' program is focused towards intelligent Autonomous Systems and Robotics \& Manufacturing.In UET, Lahore, the Department of Mechatronics \& Control Engineering (MCE), was established in December 2005. In main campus, the postgraduate and undergraduate programs were established in 1999 and 2001 respectively and are being run successfully. Of course with strong reasons, strangely, UET Lahore started postgraduate program prior to BE.

In Faisalabad campus, department of mechatronics was established in 2004. The Bachelors Programme in Mechatronics is specifically designed to cater the needs of technology-basedindustries. The objective of the programme is to enable the student to work effectively [7, 8]. In Air University, Islamabad, the Mechatronics Engineering Department, was established in 2003. Three batches with Bachelor's degrees have been graduated from the university [9]. Wah Engineering College, a constituent college of the University of Wah, was established in 2004 and has started department of mechatronics in 2005. The department of mechatronics is affiliated with UET, Taxila.

In UET, Taxila (Chakwal campus), the department of mechatronics was established in 2005 [10]. From 2011, SZABIST is being offering a four year (eight semesters) BE (Mechatronics Engineering). The BE program is essentially a day program and consists of (all electives and certain courses may be offered in the evening), Internship and the passing of the comprehensive exam. The maximum time limit to complete the $\mathrm{BE}$ degree is seven years.

A summary of the degrees being offered in mechatronics by the above mentioned universities of Pakistan are shown in the Table II. From the data of the Table II, we see that only two institutions in Pakistan are offering $\mathrm{PhD}$ degree in Mechatronics depicting that the research in the field of mechatronics is negligible as compared to other countries. The reason is the lack of teaching and research facilities in Pakistan and the general awareness about mechatronics in Pakistan. Also, out of 8 institutions, only 4 are offering MS degree in Mechatronics. The intake of students per year in $\mathrm{BS}$, MS and $\mathrm{PhD}$ in the respective universities is summarized in the Table III. From the data captured by Table III, it can be seen that very little work is being done in research field of mechatronics. The induction of $\mathrm{PhD}$ students in mechatronics is negligible in comparison with other fully developed engineering areas.
TABLE II

LIST OF UNIVERSITIES OFFERING BS, MS AND PHD IN MECHATRONICS IN PAKISTAN

\begin{tabular}{|l|c|c|c|}
\hline \multicolumn{1}{|c|}{$\begin{array}{c}\text { Name of the institutions offering } \\
\text { Mechatronics }\end{array}$} & BS & MS & PhD \\
\hline $\begin{array}{l}\text { College of Electrical and Mechanical } \\
\text { Engineering, NUST, Rawalpindi }\end{array}$ & Yes & Yes & Yes \\
\hline $\begin{array}{l}\text { University of Engineering and } \\
\text { Technology, Lahore (Main Campus) }\end{array}$ & Yes & Yes & Yes \\
\hline Air University, Islamabad & Yes & Yes & $\mathrm{X}$ \\
\hline $\begin{array}{l}\text { University of Engineering and } \\
\text { Technology, Lahore (Faisalabad Campus) }\end{array}$ & Yes & $\mathrm{X}$ & $\mathrm{X}$ \\
\hline $\begin{array}{l}\text { Wah Engineering College, Wah Cantt } \\
\text { (affiliated with University of Engineering } \\
\text { and Technology, Taxila). }\end{array}$ & Yes & $\mathrm{X}$ & $\mathrm{X}$ \\
\hline $\begin{array}{l}\text { University of Engineering and } \\
\text { Technology, Taxila (Chakwal Campus) }\end{array}$ & Yes & $\mathrm{X}$ & $\mathrm{X}$ \\
\hline $\begin{array}{l}\text { NWFP University of Engineering \& } \\
\text { Technology, Peshawar (Main Campus) }\end{array}$ & Yes & Yes & $\mathrm{X}$ \\
\hline $\begin{array}{l}\text { SZABIST Karachi } \\
\text { Yes }\end{array}$ & $\mathrm{X}$ & $\mathrm{X}$ \\
\hline
\end{tabular}

TABLE III

RECORD OF STUDENTS INTAKE IN BS, MS AND PHD IN MECHATRONICS IN UNIVERSITIES OF PAKISTAN

\begin{tabular}{|l|c|c|c|}
\hline \multicolumn{1}{|c|}{$\begin{array}{c}\text { Name of the institutions offering } \\
\text { Mechatronics }\end{array}$} & BS & MS & PhD \\
\hline $\begin{array}{l}\text { College of Electrical and Mechanical } \\
\text { Engineering, NUST, Rawalpindi }\end{array}$ & 75 & 35 & $1-2$ \\
\hline $\begin{array}{l}\text { University of Engineering and } \\
\text { Technology, Lahore (Main Campus) }\end{array}$ & 60 & 40 & $2-3$ \\
\hline $\begin{array}{l}\text { Air University, Islamabad } \\
\text { University of Engineering and } \\
\text { Technology, Lahore (Faisalabad } \\
\text { Campus) }\end{array}$ & 20 & $\mathrm{X}$ & $\mathrm{X}$ \\
\hline $\begin{array}{l}\text { Wah Engineering College, Wah } \\
\text { Cantt (affiliated with University of } \\
\text { Engineering and Technology, } \\
\text { Taxila). }\end{array}$ & $*$ & $\mathrm{X}$ & $\mathrm{X}$ \\
\hline $\begin{array}{l}\text { University of Engineering and } \\
\text { Technology, Taxila (Chakwal } \\
\text { Campus) }\end{array}$ & 50 & $\mathrm{X}$ & $\mathrm{X}$ \\
\hline $\begin{array}{l}\text { NWFP University of Engineering \& } \\
\text { Technology, Peshawar (Main } \\
\text { Campus) }\end{array}$ & 30 & $*$ & $\mathrm{X}$ \\
\hline \begin{tabular}{l} 
SZABIST Karachi \\
\hline
\end{tabular} & $\mathrm{X}$ & $\mathrm{X}$ \\
\hline
\end{tabular}

* data not available 
Only 8 institutions in Pakistan are currently offering Mechatronics Engineering. Out of these 8, 6 institutions are in Punjab and only one in Khyber Pakhtunkhuwa and one in Sindh. In Baluchistan not even a single university is offering Mechatronics.

So the need is to create awareness about mechatronics in society and emphasize on the importance of mechatronics among the students as well as industry. So, that the industries socially pressurize educational institutions to start more mechatronics programs. In this way, more students will get enrolled degrees in mechatronics and work in industries to meet the demands of society. As shown in Figure1, there is a need to promote mechatronics in Baluchistan zone, as there is not a single university offering Mechatronics in that region.

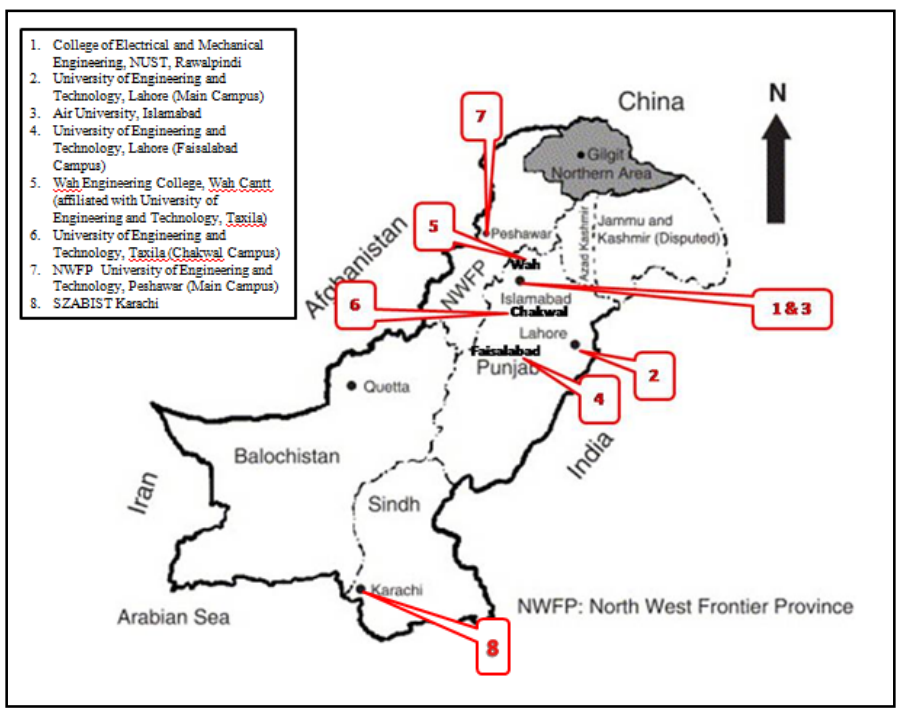

Figure 1. Location of institutions in Pakistan offering Mechatronics [11]

With the advancement of technology, the products and systems are changing rapidly into mechatronic, so, it has become essential for engineers and technicians to be "multicraft" or "Multi-skill". Multi-skill engineers and technicians know all or most of the different systems linked with mechatronics. They are able to perform traditional and conventional technical tasks and responsibilities, i.e., the installation, maintenance, troubleshooting, calibration and repair of equipment. Unfortunately, most of the fresh technicians have done graduation from programs that give training of only one or two of the areas that fall under the category of mechatronics.

Generally, the technicians become proficient in mechatronic systems by on-the-job training and learn by experience. However, companies, in general, want and see significantly those people who have formal mechatronic training.

\section{A. Mechatronics Industry Survey}

Figure 2 depicts the industrial map of Pakistan. A Survey containing questionnare related to Mechatronics was carried out to have an overview of the status of mechatronics and mechatronics engineers in industries where seemingly mechatronics related work was being done.

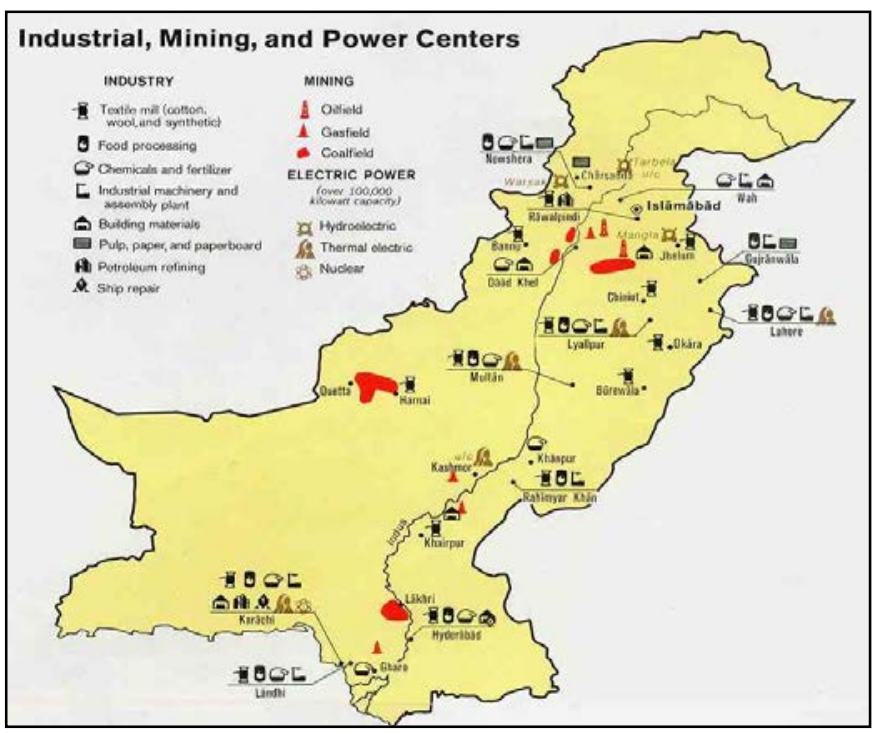

Figure 2. Industrial Map of Pakistan [12]

The questionnaire was sent to many industries, mining and power centers of Pakistan. In accordance with the response and the data we received after the survey, the results are compiled and discussed in the next section.

\section{B. Survey Results}

Most of the companies that participated in the survey belong to private sector. These participants belong to the following industries:

- Oil and Gas

- Clothing

- Food Processing

- Plastic products

- Automotive

The services offered at the participating companies are:

- Training / Consulting

- Maintenance

- Design \& Development

- Instrumentation

- Production

- Maintenance

- Sales

Figure 3 shows that $90 \%$ of the companies that participated in the survey have more than 30 engineers working in that company. Only $10 \%$ of the participants have less than 10 engineers in their company.

This means still there are some companies in Pakistan where there is deficiency of engineers and these companies are finding some difficulty to hire engineers. 


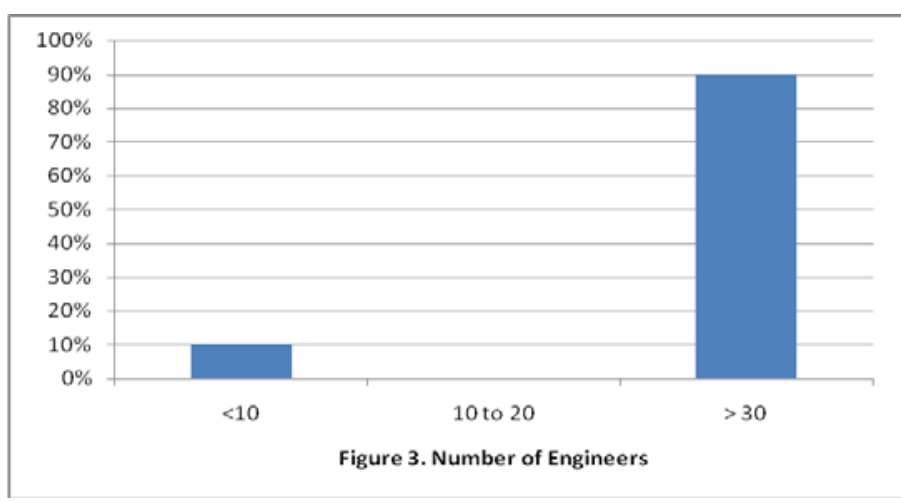

Figure 4 shows the percentage of importance of the duties that engineers perform while working in companies. This result will help fresh engineers to get awareness so that they can expertise in these areas and tasks which engineers perform in industries.

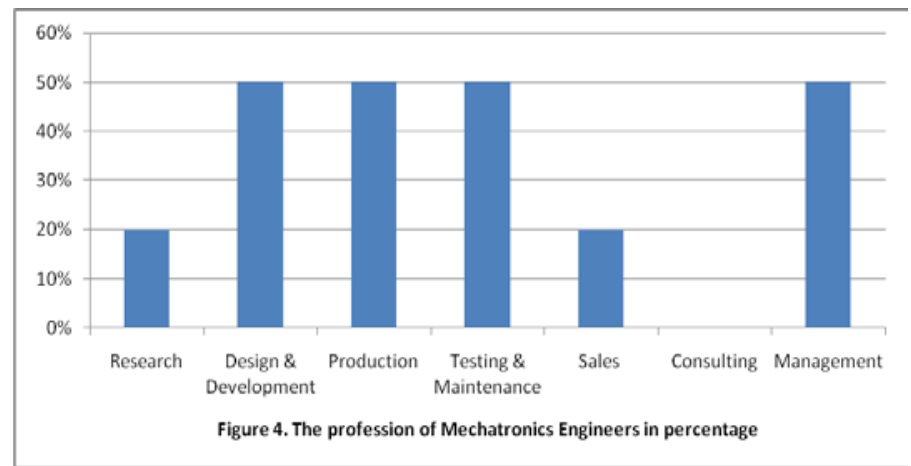

From Figure 4, we see that Design \& Development, Production, Testing \& Maintenance and Management tasks are equally important in almost all the industries.

Interest of engineers at companies in obtaining masters degree is shown in the Figure 5.

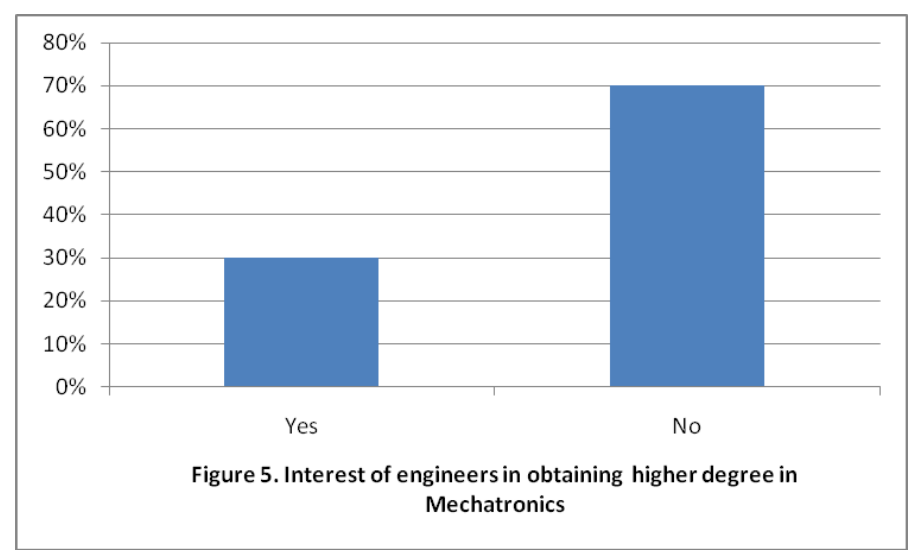

Figure 5 shows only 30\% engineers are interested in studying further and obtaining Masters Degree.

There are no particular reasons for not studying further and lack of interest in doing Masters but might be the jobs are too hectic that it is not feasible for engineers to study with job or might be they are too satisfied with their jobs and salaries that they are not getting interest in obtaining Masters Degree.
Survey was conducted to know the importance of the 13 subject areas in industries shown in Figure 6. The percentage of each area in the figure depicts its importance in the industry. This result will help and work as guideline for the fresh engineers to get expertise in the areas that are of more importance in industry. In Figure 6, the most important areas in industry are related to Mechatronics Engineering. So, consciously or unconsciously, industries are moving towards Mechatronics technology but there is not enough awareness that these areas lie in Mechatronics domain.

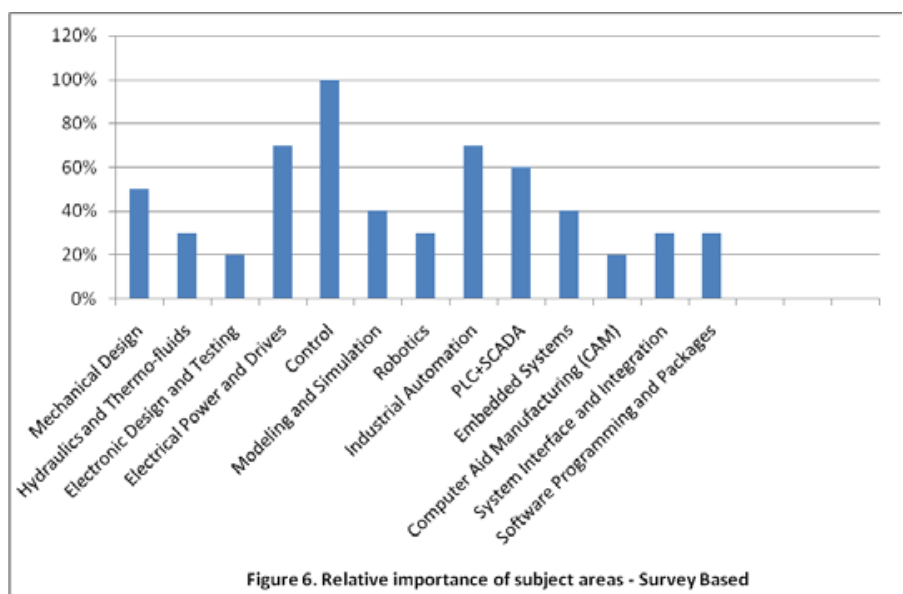

Knowledge of companies about Mechatronics Engineering is depicted in Figure 7 as follows:

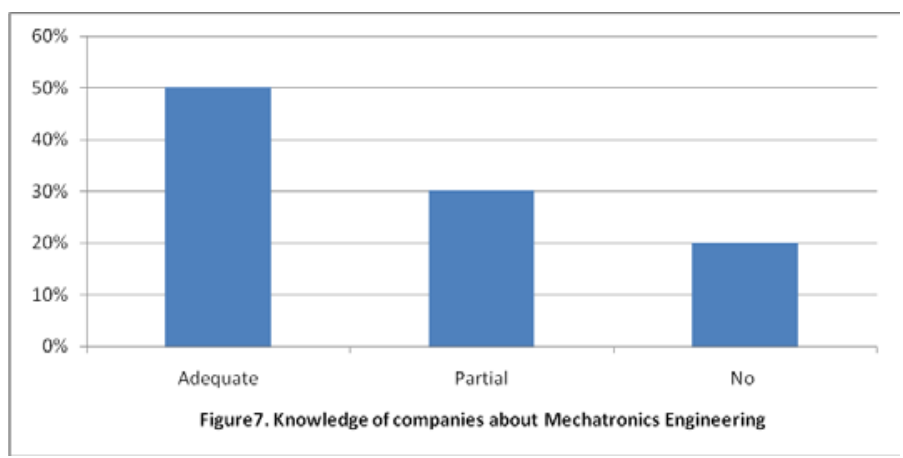

Only $50 \%$ of the participating companies had adequate knowledge of Mechatronics Engineering, 30\% said that they partially know about it and they have knowledge about either electronics or mechanical part of it, $20 \%$ of companies did not even hear about Mechatronics Engineering or did not like to discuss anything about it. Participating companies were asked about the advertisement of job vacancies having title 'Mechatronics Engineer'. The results are shown in Figure 8.

The results show that only $20 \%$ of the companies said that they advertise jobs by the title of Mechatronics Engineer rest of the $80 \%$ said that there is no job vacancy in their company specific for a Mechatronics engineer. 


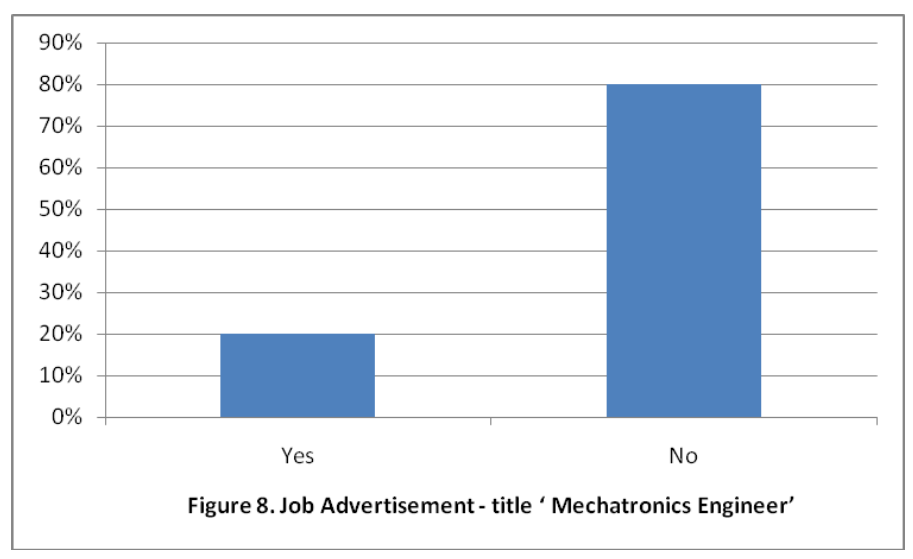

Rather they advertise jobs as 'Automation Engineer or Electrical Engineer' and sometimes consider Mechatronics Engineers for this job. The number of Mechatronics Engineers in the participating companies is shown in Figure 9 as follows:

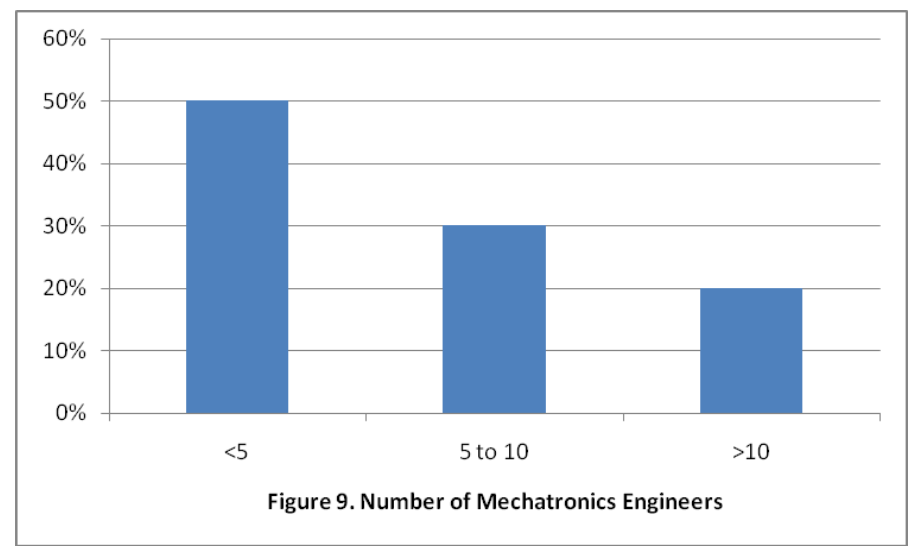

From the survey result we see that Mechatronics Engineers are not hired in the industries in appreciable number. The industries involving automotive, clothing and plastic products have very less number of Mechatronics Engineers. Only 10\% of the companies have more than 10 Mechatronics engineers as their employees. Rest of the $90 \%$ has less than 10 Mechatronics Engineers and these are categorized under Automation Engineer rather Mechatronics Engineer.

In the survey, the industries were asked about the reasons of hiring Mechatronics Engineers in their companies. A mixed response was received. Some of the companies said they are brilliant and are capable of multi-tasking, they can perform the tasks of Mechanical as well as Electrical engineers. Some said they are hired just because they are Engineers like any other Engineer; there is no special reason to hire them.

Some of the companies said because of the automation skill, Mechatronics Engineers are hired. Some said Mechatronics Engineers can work as an Electrical engineer too, so they are hired for the post of Electrical Engineer.

Companies were asked whether they hire female Mechatronics Engineers or not. This was done to know if industries accept female Mechatronics Engineers. The results are shown in Figure 10.

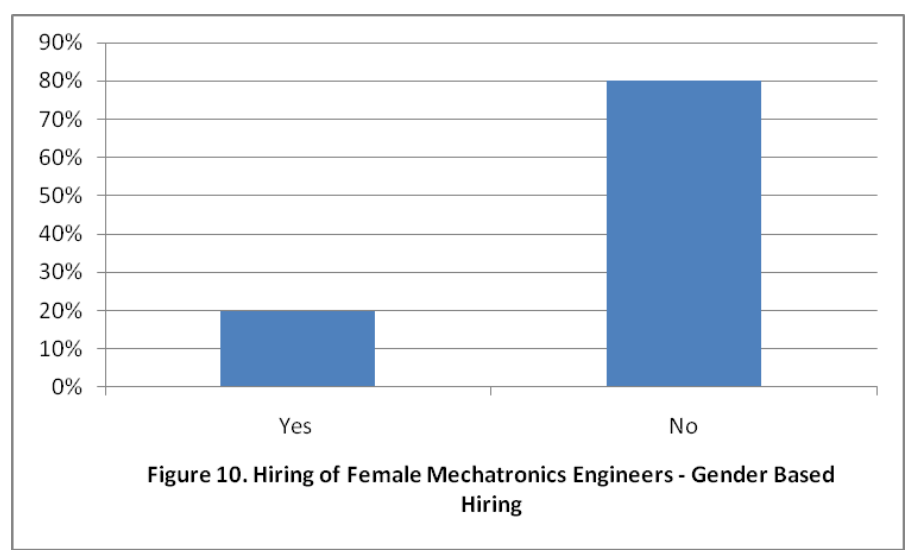

The survey results show that $80 \%$ of the industries do not hire female Mechatronics Engineer in their companies. This is really a drawback of our country where females are competing with males in every field of life and are even excelling them but they are not provided enough opportunities to work in the industrial environment. In every Engineering institution which offer Mechatronics engineering, almost $40 \%$ of each batch comprise of female students and they are more competent but many of the industries do not accept females engineers.

In the survey, companies were asked how they would compare performance of Mechatronics Engineer with that of Electrical and Mechanical Engineers in the company. The results are shown in Figure 11, 12 and 13.

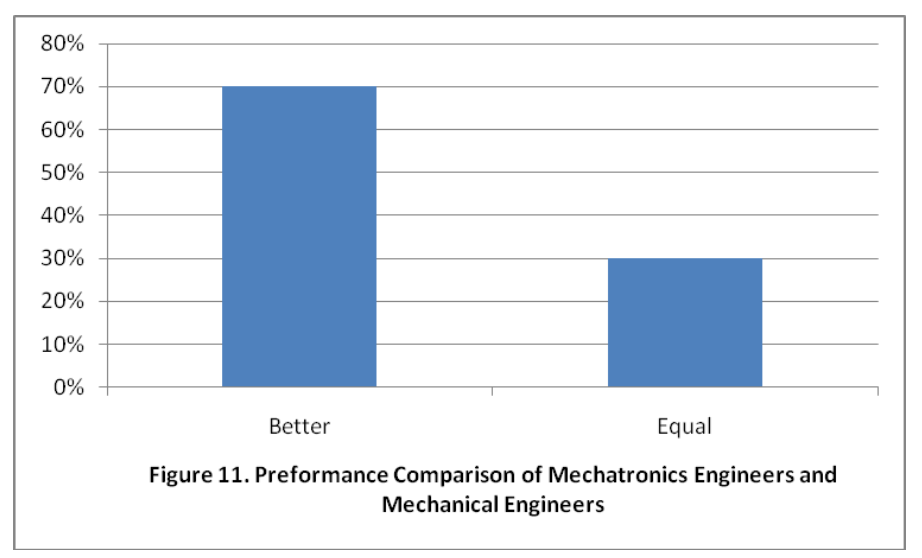

$70 \%$ of the companies realize that Mechatronics are better in performance than Mechanical engineers because of their automation skills. The rest of $30 \%$ were of the view that Mechatronics Engineers are same in performance as Mechanical Engineer.

$55 \%$ of the companies found Mechatronics engineers equal in performance with that of Electrical Engineers but if we see the survey results of Figure 12 and 13 collectively, we observe that as a whole the performance of Mechatronics Engineers are better than both Electrical and Mechanical Engineers i.e. $70+45=115$ while Electrical and Mechanical Engineers collectively score only 85 . Figure 13 shows this score result. 

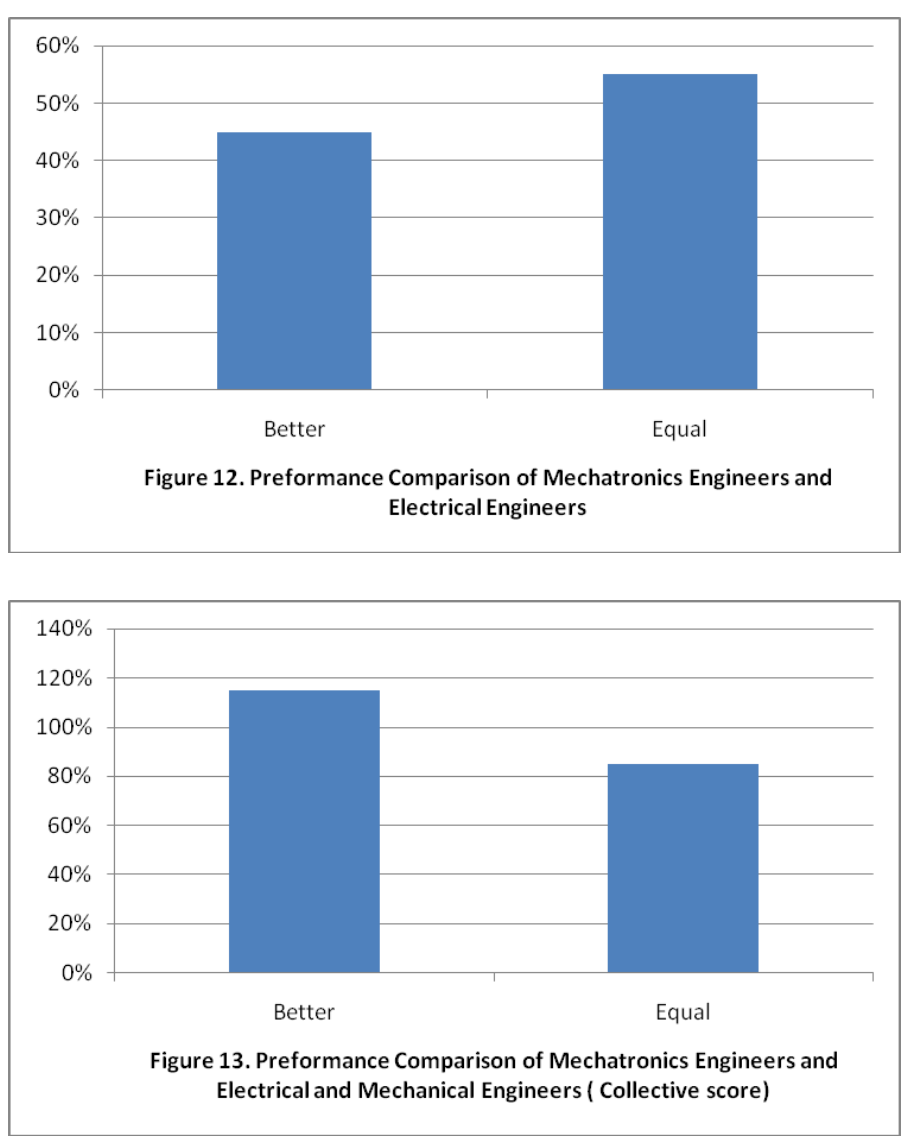

Figure 14 shows the result of willingness of companies to recruit more Mechatronics Engineers in future. The results depict a mixed response. $40 \%$ of the industries showed willingness to recruit more Mechatronics Engineers because of their better performance. 30\% said they do not need Mechatronics Engineers in their companies while 30\% of the companies were not sure of recruiting more Mechatronics Engineers in future.

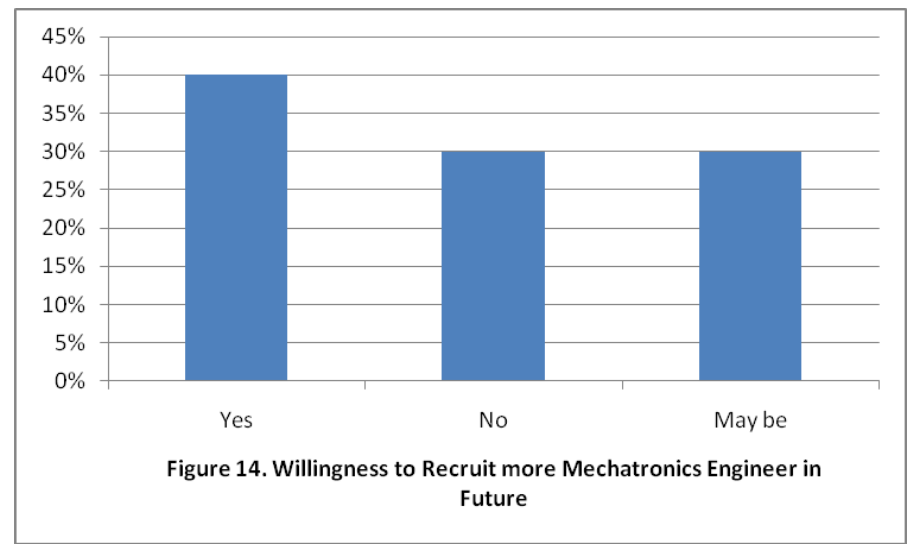

The results show that $90 \%$ the companies do not have technicians that have mechatronics background. $90 \%$ of survey results show that technicians and engineers in industries require Mechatronics training to make them capable in the industrial working environment. This result is shown in Figure 16.
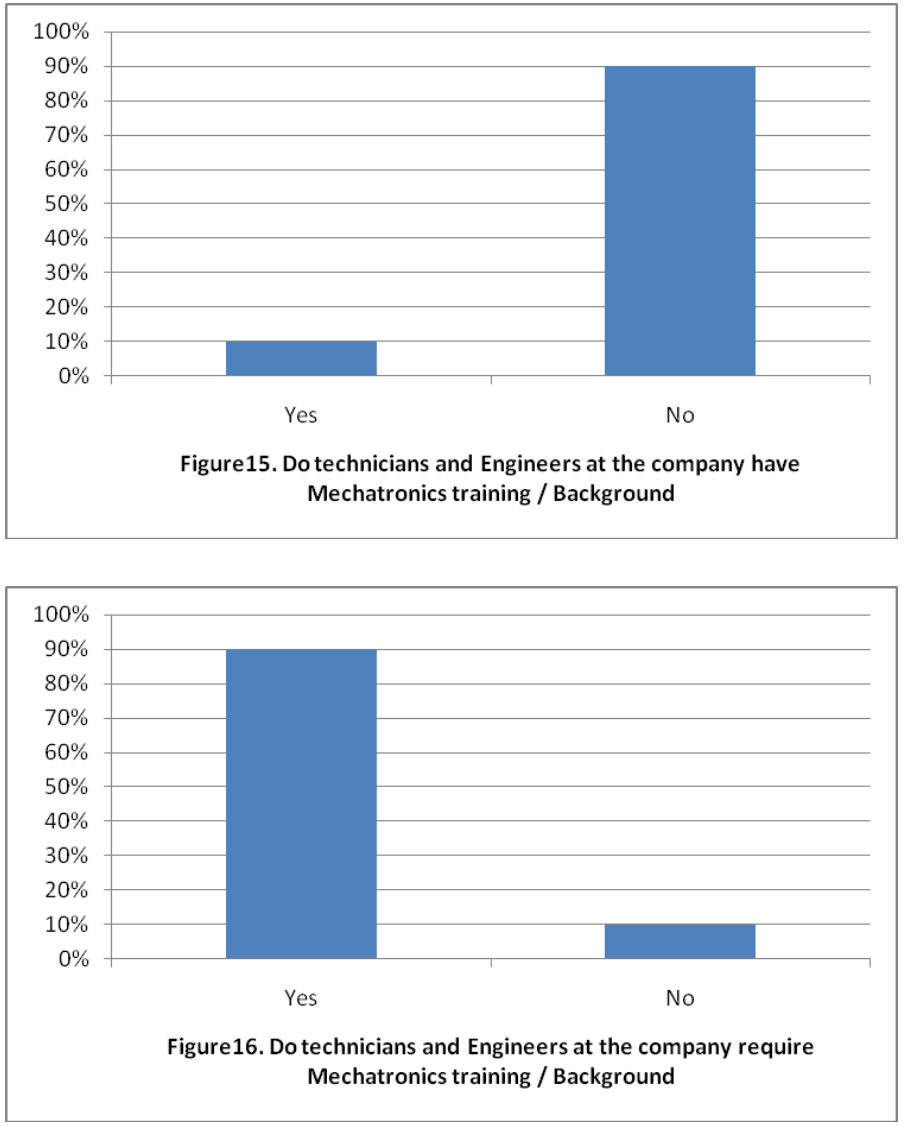

The participating companies themselves realized that their technicians and engineers need to develop mechatronics and automation skills to perform better yet most of them are reluctant to hire Mechatronics Engineers and advertise jobs by the title of Mechatronics Engineer. Rather they prefer to hire Electrical or Mechanical Engineers and train them with mechatronics skills. Awareness needed to be created in industries to highlight the importance or hiring more Mechatronics Engineers as they are more capable of performing the tasks that are of importance in industries.

\section{Summary of the Survey}

The results of the survey are summarized as follows:

\section{1) Findings}

1. R \& D department of the industries are not adequately developed.

2. Very less Mechatronics engineers are being hired in the industries.

3. No job title of 'Mechatronics Engineer' exists.

4. Mechatronics Engineers are hired for job titles of 'Automation Engineer' or 'Electrical Engineer'.

5. By doing survey we came to know people in industry with Electrical, Electronics or Mechanical background do not have complete knowledge of Mechatronics.

6. Most of the industries are not willing to hire female Mechatronics Engineers. 
7. Most of the industries said that Mechatronics Engineers are better in performance than Electrical and Mechanical Engineers.

8. Technicians at the industries do not have former training of Mechatronics.

9. Technicians and Engineers have to get Mechatronics training to work in the industrial environment.

\section{2) Recommendations}

R \& D department of the industries should be developed and industries should be motivated to do research projects with universities in order to provide the opportunity to the graduate students to work for the benefits of industry as well as society. A campaign should be started in order to create awareness among society and industry about Mechatronics Engineering. This can be done through arranging seminars and using electronic media. Awareness campaign should be initiated immediately.

\section{RELIABILITY ANALYSIS OF MECHATRONICS INDUSTRY SURVEY}

In SPSS, Cronbach Alpha is an important concept in the evaluation of assessments and questionnaires [13]. It is mandatory that assessors and researchers should estimate this quantity to add validity and accuracy to the interpretation of their data. Alpha was developed by Lee Cronbach to provide a measure of the internal consistency of a test or scale; it is expressed as a number between 0 and 1 . Internal consistency describes the extent to which all the items in a test measure the same concept or construct and hence it is connected to the interrelatedness of the items within the test. There are different reports about the acceptable values of alpha, ranging from 0.70 to 0.95 . A maximum alpha value of 0.90 has been recommended. High quality tests are important to evaluate the reliability of data supplied in an examination or a research study. Alpha is a commonly employed index of test reliability.

Reliability analysis of the data related to mechatronics industry survey compiled in form of graphs is done using SPSS by computing Cronbach alpha value.

After doing statistical analysis, we have got Cronbach alpha value as ' 0.849 '. From this high value we conclude that the survey data is valid and accurate and the results are reliable.

\section{CONCLUSIONS: MECHATRONICS PERSPECTIVES}

The increase in the worth of mechatronics in the world is because of the power, uniqueness and versatility of mechatronics. This makes all engineers think of being getting familiar with the basic theory and engineering practice of mechatronics. Mechatronics is such a wide field that there is no end limit to the application of mechatronics and to the contribution that is further added by mechatronics to the concept of inter-discipline. But the mechatronics engineers in Pakistan have to face many problems in seeking appropriate jobs because of the lack of awareness in the industries as well as society of Pakistan regarding mechatronics engineers. It is expected that in the years to come, Mechatronics will gain the status of most important engineering discipline in Pakistan from industrial point of view and mechatronics engineers will be in great demand.

\section{ACKNOWLEDGEMENT}

I would like to acknowledge my research supervisor for providing guidance and support to me. I would like to thank my family, friends and colleagues who shaped my experience both in educational and practical life. Without their support and encouragement, I would not be where I am today.

\section{REFERENCES}

[1] Armytage,W.H.G, A Social History of Engineering London Faber

[2] Buchanan, R. A. 1985. The rise of scientific engineering in Britain. British Journal for the History of Science,18: 218-33

[3] Burstall, A. F. 1963. A History of Mechanical Engineering. London: Faber and Faber.

[4] Anderson, J. D. 1997. A History of Aerodynamics and its Impact on Flying Machines. New York: Cambridge University Press.

[5] The Straight Dope on Mechatronics, By Todd Rohde, Yaskawa America, Inc. - Drives \& Motion Division, April 2008

[6] Mechatronics Engineering in Pakistan, Nauman Naseer, July 10,2011.

[7] http://www.nust.edu.pk/INSTITUTIONS/Colleges/CEME 2012 @ All rights reserved, Dated: 24.01.2013

[8] http://www.uet.edu.pk/faculties Copyright @2011 University of Engineering \& Technology, Lahore, Dated: 24.01.2013

[9] http://www.au.edu.pk/dept mts eng intro.aspx Copyright @ 2011 Air University, Islamabad. Dated: 24.01.2013

[10] http://web.uettaxila.edu.pk/uet/chakwal/mechatronics.html Copyright (C) 2012 - All Rights Reserved. Sub-Campus Chakwal, UET Taxila, Dated: 24.01.2013

[11] http://www.pakistanpaedia.com Dated: 04.02.2013

[12] http://sc.leadix.com/mechatronics/article Dated: 04.02.2013

[13] Tavakol M, Mohagheghi MA, Dennick R. Making sense of Cronbach alpha, International Journal of Medical Education. 2011; 2:53-55

\section{Creative Commons Attribution License 4.0 (Attribution 4.0 International, CC BY 4.0)}

This article is published under the terms of the Creative Commons Attribution License 4.0 https://creativecommons.org/licenses/by/4.0/deed.en_US 